\title{
The Influence of Organizational Culture, Competence and Work Motivation Towards Employee Performance
}

\author{
PJP Ginting*, Sarton Sinambela, Dessy Marhandrie, Elik \\ Universitas Tantular University \\ Jakarta, Indonesia \\ *pjpginting61@gmail.com
}

\begin{abstract}
The purpose of this study was to analyze and test the influence of leadership, competence, and motivation on the performance of the State Civil Apparatus in the Regional Office of the Ministry of Law and Human Rights of Jakarta City, partially or simultaneously. This study uses quantitative methods, with simple linear regression analysis and multiple linear regression with a sample of 136 people from a population of 205 people. To test the research instrument validity and reliability are performed. Meanwhile, the hypothesized test that performed a partial regression analysis of the t-test and multiple regression $F$ tests. Based on the results of the multiple regression analysis, the results of the leadership, competence, and motivation variables together influence the performance variable. The three independent variables, it is that leadership has the greatest influence; competence in second place; and motivation in third place. From the discussion of the results of the study, there was a significant impact of leadership, competence, and motivation jointly influencing performance. The results of the analysis and discussion of the results of this study, there is a significant influence of leadership, competence, and motivation together on the performance.
\end{abstract}

Keywords-leadership, competence, motivation, performance

\section{INTRODUCTION}

In the Indonesian Police Chief Regulation Number 14, 2018 amendment to Regulation No. 22 Year 2010 On 28 October 2010 on the Organizational Structure and Work at Level Regional Police, Division of Medicine, and Health (Biddokes) Polda Metro Jaya is a supporting element which is under Chief of Police Regional (Police Chief) who tasked with organizing medical and health development of the Police including Police Medicine and Health Services at the Polyclinic [1]. Biddokes Metro Jaya Police as an organization has a vision: "The realization of Police Medical Services and Excellent Police Health." The Biddokes work unit functions to foster and organize the function of police medicine to support the operational duties of the Jakarta Metropolitan Police and carry out daily tasks and functions with his position. In carrying out the operational duties of the police, Biddokes Metro Jaya Police is responsible for the health of police personnel and their families.

The success of national development is determined by the success of fire extinguishers in carrying out their duties, especially in terms of staffing. Therefore, the Government apparatus has a very important role and position as the motor and driver of all activities of government functions. Human Resources (HR) has become one of the sharpest highlights in the implementation of government concerning readiness, numbers, education, and professionalism. Good governance requires the support of good personnel readiness anyway-the success of achieving organizational goals that strongly influenced by the role and performance of its employees. Improved employee performance is important given the change in the direction of government policy as desired by the spirit of the reformation to more broadly provide space for the public in government and development activities where the Government and its apparatus play a greater role as facilitators.

Various aspects are interconnected and affect the success or failure of activities on a series of tasks carried out by employees in the organization. The core competencies in an organization are core competence to achieve a competitive advantage and outperformance competitors and development core competence to gain a competitive advantage so that it can increase its share of scarce resources in its environment [2] The core competencies to achieve competitive advantage and excel in competition and the core competency development to obtain competitive advantage to increase resources in the organizational environment [2]. Competence is the knowledge, expertise, and abilities that a person has, which is part of him, so he can carry out the appearance of cognition, affection, and certain psychomotor behavior [3].

Primary needs are universal and do not depend on the individual. Every individual has the same drive because it is related to the components that everyone needs to stay 
alive. However, personalities, self-concepts, social norms, and past experiences influence their secondary needs. These needs are different for each individual because it depends on the value they have, whether stronger or weaker than others. Humans will behave and make decisions based on secondary needs and values and the influence of their personalities. Therefore, people's behavior changes significantly and unpredicted without knowledge of personality [4].

Performance is job performance is the outcomes of jobs that relate to the objectives of the organization such as quality, efficiency, and other criteria of effectiveness. Job performance includes several outcomes, such as objective outcomes, personal behavior outcomes, intrinsic and extrinsic outcomes, and job satisfaction outcomes [1].

\section{METHODS}

The nature of this research, the population, is all the entire staff of the Biddokes Polda Metro Jaya, amounting to 101 respondents. With the approach of the formula Slovin where the error of $5 \%$, then the number of samples obtained for 80 people, where the technique of using random sampling.

The test results show that all the Cronbach Alpha coefficients obtained are greater than 0.60 so that the points of the statement can be declared reliable. So it can be concluded that the design of a questionnaire designed to measure variables organizational culture, competence, work motivation, and employee performance is reliable or trustworthy to measure all the variables in the study. After the instruments used in this study are valid and reliable, then further data calculations can be performed.

\section{RESULTS AND DISCUSSION}

\section{A. Result}

The coefficient of determination of variable organization culture, competence, and work motivation on employee performance is 0.496 . This value indicates that Organizational Culture, Competence influence $49.6 \%$ of the variation in employee performance, and Work Motivation while the remaining $55.4 \%$ is influenced by other variables outside of this research, such as job satisfaction, training, career paths, rewards, and others.

F-test for variables Organizational Culture, Competencies, and work motivation on the performance of employees can be seen in the following table:

TABLE I. ANOVA JI U RESULTS

\begin{tabular}{|l|l|l|l|l|c|c|}
\hline \multicolumn{2}{|c|}{ Model } & Sum of Squares & df & Mean Square & F & Sig. \\
\hline \multirow{3}{*}{1} & Regression & 825,821 & 3 & 275,274 & 24,901 & $.000^{\mathrm{b}}$ \\
\cline { 2 - 8 } & Residual & 840,167 & 76 & 11,055 & & \\
\cline { 2 - 7 } & Total & 1665,988 & 79 & & & \\
\hline
\end{tabular}

Based on the results of multiple regression analysis the influence of Organizational Culture (X 1) on Work Motivation (X3) obtained regression coefficient $\beta 1=0.329, \beta 2=0.204$ and $\beta 3=0.225(\beta 1 \neq \beta 2 \neq \beta 3)$ with $\mathrm{F}$ arithmetic $=24,901$, while the $\mathrm{F}$ table value $=2.72(\alpha=0.05 ; \mathrm{df}=76)$. Therefore, $\mathrm{F}$ count $>\mathrm{F}$ table, and $\mathrm{n}$ use values obtained significantly is 0,000 less than 0.05 then $\mathrm{H} 0$ is rejected, $\mathrm{H} 1$ accepted and it can be concluded that there are significant organizational culture (X1), Competence (X2) and Work Motivation (X3) simultaneously or together towards Performance (Y)

$\mathrm{T}$ statistical tests aimed at assessing how far the influence of the independent variables $\mathrm{X} 1, \mathrm{X} 2$, and $\mathrm{X} 3$ on the dependent variable $\mathrm{Y}$ with other independent variables constant. So testing statistics $t$ is used to determine if there is a partial effect between Organizational Culture, Competencies, and Work Motivation to employee performance. In this test, if t count > $\mathrm{t}$ table, then it means there is a statistically significant influence between the independent variable on the dependent variable. To see the magnitude of $t$ can be seen on the table following the overall load on the data processing for the t-test is already listed.

TABLE II. TEST RESUlTS OF COEFFICIENTS

\begin{tabular}{|c|c|c|c|c|c|}
\hline \multirow[b]{2}{*}{ Model } & \multicolumn{2}{|c|}{$\begin{array}{l}\text { Unstandardized } \\
\text { Coefficients }\end{array}$} & \multirow{2}{*}{$\begin{array}{c}\begin{array}{c}\text { Standardized } \\
\text { Coefficients }\end{array} \\
\text { Beta }\end{array}$} & \multirow[b]{2}{*}{$\mathbf{t}$} & \multirow[b]{2}{*}{ Sig. } \\
\hline & B & Std. Error & & & \\
\hline \begin{tabular}{l|l}
1 & (Constant) \\
\end{tabular} & 21,310 & 4,246 & & 5,019 & 9.000 \\
\hline $\begin{array}{l}\text { Organizational } \\
\text { Culture }(\mathrm{X} 1)\end{array}$ & .329 & .089 & .329 & 3,676 & 6.000 \\
\hline Competence (X2) & .204 & .061 & .300 & 3,332 & 2.001 \\
\hline $\begin{array}{ll}\text { Work } & \text { Motivation } \\
\text { (X3) } & \end{array}$ & .225 & .067 & .307 & 3,388 & 8.001 \\
\hline
\end{tabular}

\section{B. Discussion}

The unstandardized coefficients column is used to make structural equations. The magnitude of the path coefficients for Organizational Culture $=0.329$, Competence $=0.204$, and Work Motivation $=0.225$, then the equation was modeling Organizational Culture (X1), Competence (X2), work motivation (X3) on employee performance (Y).

Based on the results of multiple regression analyses, the influence of Organizational Culture (X1) on Performance (Y) obtained a regression coefficient $\beta_{1}$ of 0.329 with arithmetic $=$ 3.676, while the value of $t_{\text {table }}=1.99(\alpha=0.05 ; \mathrm{df}=$ 76). Therefore, count $>$ table a significance level of 0.000 $<0.05$, then $\mathrm{H}_{0}$ is rejected, $\mathrm{H}_{1}$ accepted. Thus it can be concluded that Organizational Culture has a positive effect on performance.

Based on the results of multiple regression analyses, the influence of Competence (X2) on Performance (Y) obtained a regression coefficient $\beta_{2}$ of 0.204 with $t_{\text {arithmetic }}=3.332$, while the value of $t_{\text {table }}=1.99(\alpha=0.05 ; \mathrm{df}=76)$. Therefore, $\mathrm{t}_{\text {count }}>$ $\mathrm{t}_{\text {table }}$ at a significance level of $0.001<0.05$, then $\mathrm{H}_{0}$ is rejected, $\mathrm{H}_{1}$ accepted. Thus it can be concluded that competence has a positive effect on performance. 
Based on the analysis of multiple regression analyses, the effect of Work Motivation (X) on Performance (Y) obtained a regression coefficient $\beta_{3}$ of 0.225 , with $t_{\text {arithmetic }}=3.388$, while the value of $\mathrm{t}_{\text {table }}=1.99(\alpha=0.05 ; \mathrm{df}=76)$. Therefore, $\left.\mathrm{t}_{\text {count }}\right\rangle$

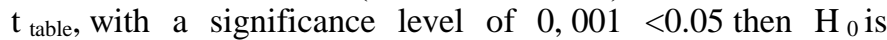
rejected, $\mathrm{H}_{1}$ accepted. Thus it can be concluded that work motivation has a positive effect on performance.

The results of several empirical studies have shown that organizational culture has a significant contribution to employee performance. Organizational culture has an important role in achieving the best performance of employees. A good organizational culture will lead to good performance for employees and the better the culture of the organization, the performance tends to increase. The results of this study are the same as what was explained in previous studies where he stated that organizational culture influences employee performance of 0.029 [5].

This study found that the two variables have a strong relationship that is equal to 0.853 . Which concluded in his research that competence influences employee performance so that with the competency of employees, the organization can encourage increased employee performance [6].

The results of this study are the same as the previous studies above. In this study, the competence variable on performance influences $(\mathrm{P}=0.01)$. Both have a strong relationship that is 0.848 .

Internalization of work motivation by service organizations for employees needs to be embedded in a system. The effect of work motivation is related to performance in the form of employee morale in work behavior, which in turn will meet the output according to organizational expectations. A similar explanation, who concluded their research that there is an influence of work motivation on employee performance of 0.804 [5].

The results of this study are the same as the previous studies above. In this study, work motivation variables on performance influence $(\mathrm{P}$-value $=0.01)$. Both have a strong relationship that is 0.850 . From the results of the regression coefficient above, the most dominant variable affecting the Performance of Employees is Work Motivation, while the Competency variable is the variable that has the smallest influence on the performance employees.

\section{CONCLUSION}

The results of this study indicate that employee performance was strongly influenced by work motivation. By further increasing employee work motivation, the performance of employees in any organization will be improving. The independent variables that have a significant effect partially or simultaneously on performance. Therefore, further research needs to be done as future development. For advanced research model that was made by organizational culture influences performance through the mediation of work motivation. Likewise, competence influences performance through mediating work motivation.

\section{REFERENCES}

[1] J.L. Gibson, Organizations: Behavior, Structure, Process. New York: McGraw-Hill Int., 2013.

[2] Jones 2015. Organizational Behavior. New York: McGraw-Hill Int, Kreitner, Robert, and Kinicki, Angelo, (2018), Organizational Behavior. New York: McGraw-Hill Inc.

[3] Tjahjono and Gunarsih, "Pengaruh Motivasi Kerja dan Budaya Organisasi terhadap Kinerja Pegawai di Lingkungan Dinas Bina Marga Prov. Jawa Tengah,” Jurnal Ekonomi. Jawa Tengah, 2015.

[4] McShane and Glinow, Von. Organizational Behavior: Emerging Knowledge, Global Reality. Singapore: McGraw-Hill Education, 2016.

[5] Peraturan Kepala Kepolisian RI No. 22 Tahun 2010, Susunan Organisasi dan Tata Kerja pada Tingkat Kepolisian Daerah, Bidang Kedokteran, dan Kesehatan (Biddokes) Polda Metro Jaya, 2010.

[6] N. Marlina, "Pengaruh Budaya Organisasi, Kompetensi Kerja dan Motivasi Kerja terhadap Kinerja Karyawan PT. Taspen KCU Bandung." Jurnal Fakultas Ekonomi dan Manajemen. Bandung: Unpas, 2016. 